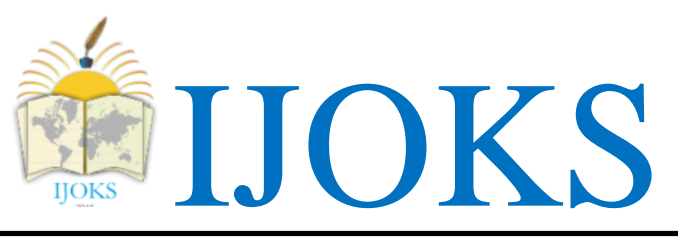

International Journal of Kurdish Studies

(ISSN:2149-2751)

5 (1), pp. $359-362$

http://www.ijoks.com

\title{
İran'ın Irak Kürdistan Bölgesel Yönetimi’nin (IKBY) Bağımsızlık Girişimlerine Bakışı
}

Mehmet Akif KOÇ ${ }^{1}$

Received: Nov 15, 2018 Reviewed: Nov 30, 2018 Accepted: Dec 07, 2018

\section{Recommended citation:}

Koç, M.A. (2019). İran'ın Irak Kürdistan Bölgesel Yönetimi'nin (IKBY) Bağımsızlık Girişimlerine Bakış1. International Journal of Kurdish Studies 5 (1), 359 - 362 DOI: 10.21600/ ijoks.516512

IKBY Dış İlişkiler Departmanı Başkanı Falah Mustafa, 21 Eylül 2017 günü CNN canlı yayınında "Irak sınırları içerisinde bir geleceğimiz olduğunu düşünmüyoruz" açıklamasını yaptı. Aslında bu cümle, çok uzun bir geçmişi bulunan Irak Kürtlerinin (ve daha genel anlamda Ortadoğu'da yaşayan tüm Kürt topluluklarının) içerisinde yaşadıkları sınır hatlarıyla olan ilişkilerinin doğasını göstermesi bakımından jenerik ve somut bir anlama sahip.

$\mathrm{Bu}$ cümlenin hemen hemen bir benzerinin, mesela dört yüz yıl önce Senendec'deki bir Ardalan Emirinden Safevî İran Şahı'na veya iki yüz yıl önce Süleymaniye'deki bir Bâbân Paşasından bağlı bulunduğu Bağdat'taki Osmanlı Valisine yönelik olarak dile getirilmiş olabileceğini tahayyül etmek zor değil. Tarih bunun somut örnekleriyle dolu: Kürtlerin, her dönemde, içinde yaşadıkları sınırlarla ihtilafları oldu.

Birkaç gün sonra, 25 Eylül 2017 tarihinde, Kuzey Irak’ta bağımsızlık referandumu gerçekleştirildi; sonucundan bağımsız olarak Irak Kürtleri kritik bir dönemece daha girdi bu referandumla. Son çeyrek asırda, her birkaç yılda bir girdikleri gibi. Kürtlerin Soğuk Savaş

\footnotetext{
${ }^{1}$ Corresponding Author: Ph.D Can., Middle East Studies, Ankara / Turkey, E-mail: akifkoc@hotmail.com, ORCID NO : https://orcid.org/0000-0001- 5179-6027
} 
sonrası bölgesel ehemmiyet kazanmaya başladıkları 1991'den, yani Saddam Hüseyin'in Kuveyt'i işgaliyle başlayan Körfez Savaşı'ndan beri; belki de ilk kez, bir adım atınca, içinde Kürtlerin yaşadığı üç bölge ülkesini birden karşılarında buldular, buna iç savaş içindeki Suriye’yi de katmak mümkün. Daha önce hemen her adımlarında, örtülü veya açık şekilde bu dört ülkeden birini/birkaçını yanlarında bulurlardı, fakat bu sefer konu "bağımsızlık" ve tabiatıyla herkes karşılarında.

Bu cepheleşme, BM Genel Kurul Toplantıları marjında New York'ta bulunan Türkiye, Irak ve İran Dışişleri Bakanlarının, 20 Eylül 2017 günü referandum konulu tek gündem maddesiyle bir araya gelmeleriyle somutlaştı. Her üç ülke yetkilileri de, bağımsızlık bir yana, referandumun gerçekleştirilmesine dahi şiddetle karşı olduklarını ve bunun bölgede önlenemez bir çatışma ve istikrarsızlık sarmalının kapısını açabileceği konusunda hemfikir. Ankara, 22 Eylül'deki MGK kararları ve tarihe atıflarla bu mesajı iyice sertleştirdi.

Her devlet kendi perspektifinden haklı sebeplerle bu referanduma karşı çıkıyor. Bu meyanda, İran'ın itirazlarına daha yakından bakınca sekiz temel dinamik ön plana çıkıyor:

-İran'da yaşayan Kürt nüfus ve etnik kompozisyon

-Irak-İran ilişkileri

-Ekonomik saikler

-ABD-İsrail faktörü

-Türkiye'nin tutumu

-IŞİ'le mücadele

-Irak Kürtlerinin iç siyaseti

-İran-zemin stratejisi.

1. İran'da yaşayan Kürt nüfus ve etnik kompozisyon: Her ne kadar İran'da etnik verilere dayalı nüfus kayıtları tutulmasa da, ülkede farklı kaynaklara göre ortalama 8-10 milyon civarında Kürt vatandaşının bulunduğu tahmin edilmekte, bunun da yaklaşık \% 70’i Sünni. Keza ülkede, başta Azerbaycan Türkleri olmak üzere, Fars kökenli olmayan çok sayıda etnik azınlık yaşıyor. Ülke nüfusunun kabaca yarıdan fazlası Fars kökenli değil. Bu nedenle bilhassa self-determinasyon hakkının, geçmişte politize olup İkinci Dünya Savaşı sonrası 
Sovyet güdümünde bir devletçik de kuran Kürt azınlığın yanısıra, ülkede zaten merkezi yönetimle sorunlar yaşayan Türk, Arap, Beluç vb halklara emsal olabileceği düşüncesi mevcut, hatta bazı çevrelere göre bu durum ciddi bir milli güvenlik sorunu oluşturuyor.

2. Irak-İran ilişkileri: 20. yüzyılın büyük bölümünü gerginlik ve sınır ihtilafları içerisinde geçiren iki ülke, 1980-88 yılları arasında büyük bir konvansiyonel savaş da yaşamakla birlikte, 2003'te Irak'ın işgali sonrasında ülkede, İran lehine ciddi bir stratejik firsat alanı doğdu. İşgalci güçler ve bölge ülkelerinin hatalarının yanısıra, nüfusun \% 60'dan fazlasının Şii olması ve bu grupların siyasi ve dini-kültürel olarak İran'a ziyadesiyle yakın olmalarının da etkisiyle, bu ülke Irak’ta çok önemli bir konuma yükseldi. Dolayısıyla bu kadar etkili bir pozisyonda olduğu önemli bir komşusunda, petrol-doğal gaz bağlamında zengin kaynaklara sahip, stratejik olarak da kıymetli Kuzey Irak'ın bağımsız olması kati surette İran'ın tercih edeceği bir durum değil. Bu yönde bir hareketin, Bağdat'la ilişkileri zaten oldukça problemli olan Sünni Arapları da ayrılık yönünde harekete geçirme ihtimali oldukça güçlü. Üçe bölünüp zayıflamış Bağdat-Basra hattından ibaret Irak ise, İran açısından kötü senaryo oluşturuyor.

3. Ekonomik saikler: 1991 Körfez Savaşı’ndan başlayarak İran, Türkiye'nin hemen ardından Irak Kürtlerinin ikinci önemli ticaret partneri haline geldi. Bu zamana kadar da uluslararası denizlere bağlantısı olmayan bu kapalı bölgenin ekonomik gelişiminde, biraz da paradoksal olarak, Türkiye ve İran'ın önemli katkıları oldu. Gelinen aşamada olası bağımsızlık sonrasında ABD, AB, Rusya gibi bölge dışı aktörlerin daha fazla ilgi gösterip yatırım yapacağı bölgede, ekonomik ve teknolojik anlamda geri kalmış İran'ın bu avantajı konumunu kaybedeceği aşikâr.

4. ABD-İsrail faktörü: Çoğunlukla söylem düzeyinde kalsa ve eyleme hemen hiç geçmese de, İran yönetimindeki ABD-İsrail karşıtlı̆̆ı herkesin malumu. Olası bağımsızlık sonrası ortaya çıkacak entitenin, öncelikle bu iki devlet tarafindan manipüle ve himaye edilebileceği korkusu İran'ın muhalefetini besleyen bir unsur. Hâlihazırda IKBY'deki ABD-İsrail varlığının Irak'ın bütünlüğü içerisinde dengelenmeye devam edilmesi düşüncesi İran'1n öncelikli tercihi.

5. Türkiye'nin tutumu: Son dönemde sesli olarak pek dile getirilmese de, yakın zamana kadar IKBY'nin Türkiye tarafından Bağdat'a karşı kollanıp desteklendiği görüşü İranlı karar alıcılarda etkindi. İki ülke arasında Kuzey Irak üzerindeki tarihsel jeopolitik rekabetin de etkisiyle İran tarafında, Ankara'nın şu anki söylemi ne olursa olsun, Türkiye'nin ilerleyen 
dönemde ortaya çıkacak entiteyi tanıyıp yine kanatları altına alabileceği ve İran’ı tamamen devre dışı bırakabileceği endişesi her zaman var oldu.

6. IŞİD’le mücadele: İran tarafı, son dönemde Suriye ve Irak’ta tamamen bertaraf edilmesi için çalışılan IŞİD’e karşı mücadelenin, olası bağımsızlık sonrası zayıflayabileceğinden endişeli. Bu bağlamda Bağdat-Erbil'in ortak askeri harekât icrasından, sınır güvenliğine kadar pek çok konuda yeni sorunların ortaya çıkabileceği öngörülüyor.

7. Irak Kürtlerinin iç siyaseti: Önceden beri İran, daha ziyade Süleymaniye-Kerkük ekseninde güçlü olan Talabani'nin KYB'sini desteklemekte, KYB içinden çıkıp ikinci parti haline gelen ancak IKBY idaresinden dışlanan Goran Hareketi de İran'a uzak durmamaktadır. Ancak referandum söyleminin bayraktarlığını açık şekilde Barzani’nin yapması ve olası bağımsızlık sonrasında bilhassa KYB'nin Kürt iç siyasetinde iyice zemin kaybetmesi riski İran'1 endişelendirmektedir.

8. İran-zemin stratejisi: Türkiye ve uluslararası arenada İran'ın, Irak ve Orta Doğu'ya ilgisinin mezhepsel tonu daha baskın olarak bilinse de, yaklaşık 2500 yıldır İran'ın (yönetici klan ve din-mezhep karakteristiğinden bağımsız olarak) bölgeye ilgisini jeopolitik dinamikler şekillendirmektedir. İran'ın etki alanının şu anki sınırlarının çok daha ötesinde olduğunu savunan (İran-zemin) ve bilhassa kültürel tesir sahası üzerine yoğunlaşan bu yaklaşım, Irak’1 bu alanın tarihi, coğrafi ve kültürel olarak tabii bir alt-bölgesi telakki etmektedir. Dolayısıyla İran'ın bu ülkeye yönelik politikasının temelde bu güdüyle belirlendiğini ve Irak'ın hemen her bölgesiyle ilişkilerinin dışarıya yansıyandan daha derin olduğunu hatırda tutmak gerekir. Son tahlilde İran, kendi doğal tesir sahasında, kendisine taban tabana zıt dış güçlere bağlı/bağımlı bir entitenin varlığını tehdit saymaktadır.

Sonuç olarak, yukarıdaki sekiz temel dinamik ekseninde İran, Irak Kürtlerinin bağımsızlık taleplerine karşı çıkmaktadır. Ancak, İran'daki köklü diplomasi geleneğinin her zaman esnek manevralara da müsait olduğunun ve kendi tesir alanındaki topluluklarla uzun dönemli ihtilafları sıcak çatışmaya kolay kolay dönüştürmediğinin bilinmesi faydalı olacaktır.

İran'ın Irak Kürtleriyle ilişkilerinin, 2017 Eylül ayında, son bir kez denenen ancak sonuca ulaşmayan bağımsızlık girişimleri bahsinde bir girizgâh olarak kabul edilebilecek yukarıdaki hususların ötesinde, tarihi, coğrafi, ekonomik ve kültürel veçheleriyle daha geniş analizlerle ele alınması zaruret arzetmektedir. 